\title{
Oleminen ja oppiminen
}

Jarvis, Peter, 1989. Oleminen ja oppiminen. Aikuiskasvatus 9, 3, 92-96. - Artikkeli on tutkimus oppimisen filosofiasta. Siinä esitetään vain muutamia väitteitä itse oppimisesta mutta yritetään löytää sen suhde inhimilliseen olemiseen. Suurimman osan ajasta ihmiset oppivat, sillä he eivät elä sopusoinnussa ympäristönsä kanssa. Juuri tämä saa aikaan ongelmatilanteen, josta oppimisprosessi alkaa.

\begin{abstract}
Järki, ihmisen siunaus, on myös hänen kirouksensa; se pakottaa hänet tulemaan toimeen ikuisesti sen kanssa, että hänen on ratkaistava ongelma, joka on ratkaisematon. Tässä suhteessa ihmisen olemassaolo poikkeaa kaikista muista olioista; se on jatkuvassa ja väistämättömässä epätasapainon tilassa. Ihmiselämää ei voida elää toistamalla lajityypillisiä malleja; jokaisen on elettävä se itse. Ihminen on ainoa eläin, joka voi olla ikävystynyt, joka voi olla tyytymätön, joka voi tuntea että hänet on karkoitettu paratiisista. Ihminen on ainoa eläin, jolle hänen oma olemassaolonsa on ongelma, joka hänen on ratkaistava ja jota hän ei voi paeta. Hän ei voi palata harmonian tilaan, joka vallitsi luonnossa ennen ihmistä; hänen on jatkettava järkensä kehittämistä, kunnes hän hallitsee luontoa ja itseänsä. (Fromm 1949, 40).
\end{abstract}

Juuri tätä dikotomiaa - ihmisen suhdetta ympäristöönsä - tutkitaan tässä artikkelissa. Seuraako siitä, kuten Fromm esittää, loputon etsintä, koska ihminen ei voi elää toistamalla uudelleen lajityypillisiä malleja? Tämä on kertomus Eedenin puutarhasta ja ongelmista, jotka seurasivat siitä, että ihmiskunta löysi tiedon; ehkä se oli, kuten arkkipiispa Temple kerran sanoi - lankeemus, mutta ylöspäin! Tässä on tämän artikkelin keskipiste. Ihmisellä ei ole vaistoja, ja siksi se ei voi elää lajinsa mukaisesti. Ei voi olla mitään harmoniaa ihmisen elinympäristön kanssa koska ihminen ei noin vain "sopeudu" siihen. Ihmisen on opittava tulemaan toimeen ympäristönsä kanssa - ihmisen on pakko oppia. Oppiminen alkaa aina kun tämä epätasapaino syntyy; oppiminen on selvittämättömällä tavalla kietoutunut yhteen olemisen kanssa, se on osa ihmiselämää.

Tämä eroaa melkoisesti Pavlovin koirista ja Skinnerin kyyhkysistä tehdyistä tulkinnoista. Molemmissa on kysymys oppimisesta ja molemmissa se liitetään suhteellisen välitöntä tyydytystä tuottaviin instrumentaalisiin tavoittei- siin. Tästä näkemyksestä on tullut osa sitä oppikurssia, joka jokaisen kunnon kasvattajan on käytävä läpi. Samalla kun nämä kokeet olivat ja ovat yhä tärkeitä, ovat ne erässä mielessä keinotekoistaneet oppimisen; sen sijaan tämä artikkeli pyrkii liittämään oppimisen erityisesti ihmisen olemassaoloon. Artikkeli jakaantuu kahteen osaan: ensiksi keskustellaan ihmisen ontologiasta ja toisessa osassa se liitetään oppimiseen.

\section{Oleminen}

Lapsella ei ole syntymähetkellä lajityypillisiä vaistoja vaan joitakin vietinomaisia pyrkimyksiä, jotka ohjaavat sitä etsimään tyydytystä välittömiin tarpeisiinsa. Ihmislapsella ei myöskään ole juuri kykyä selviytyä maailmassa, johon hän on syntynyt. Sillä lapselle ei ole vielä kehittynyt tietoisuutta, josta vasta jokaisen yksilön tarina alkaa. Vuorovaikutuksessa muiden kanssa, elehtien ja kommunikoiden, ihmislapsi varastoi aivoihinsa aineksia, joista tietoisuus rakentuu. Kuten Mead (Strauss 1964, 158-159) osoittaa:

Eleistä tulee merkityksellisiä symboleita silloin kun ne saavat elehtivän yksilön sisällä aikaan saman reaktion, joka näkyy tai jonka oletetaan näkyvän ulkoisesti muissa yksilöissä, joille ne osoitetaan. Koko sosiaalisten prosessien elekielessä... yksilön tietoisuuden sisältö ja merkitykset riippuvat siten siitä, miten hän ymmärtää muiden suhtautuvan omiin eleisiinsä... Tietoisuus tai älykkyys on mahdollista vain eleiden merkityksellisinä symboleina; sillä vain niiden eleiden välityksellä, jotka ovat merkityksellisiä symboleita, voi tapahtua ajattelua, joka on yksinkertaisesti yksilön sisäistynyttä tai sisäistä puhetta itselleen.

Näin ihmislapsi alkaa elämänsä alusta lähtien ja kokemuksien kautta kehittää tietoisuutta, joka kykenee antamaan kokemuksille merkityssisällön. Aluksi lapsi saa kokemukset synnyttä- 
jänsä ja kasvattajansa kanssa. Sittemmin niitä saadaan laajemmasta maailmasta. Mutta juuri tietoisuus on niiden kokemusten varasto, joita lapsella on; se on hänen oma identiteettinsä elämäkerrallinen perusta, joka ilmaantuu ja kehittyy kokemuksien kasvaessa.

Ympäröivän maailman kanssa vuorovaikutuksessa syntyy persoona, identiteetti ja ihminen, jolla on riittävästi tietoa selviytyäkseen maailman menossa. Kun tutkitaan tätä prosessia hieman yksityiskohtaisemmin, voidaan havaita että sen ytimessä on kokemusten sisäistäminen ja mieleen tallentaminen. Lapsella ei ole vaistomaisia varusteita, joiden avulla hän voisi selviytyä maailmassa etukäteen annetulla tavalla; lapsen täytyy sisäistää ja tallentaa muistiin kokemuksensa. Tästä varastosta lapsi kykenee palauttamaan mieleensä samankaltaisia kokemuksia ja vuorovaikutustilanteita. Ja tämän kokemusvarastonsa avulla lapsi kykenee selviytymään tulevaisuuden tapahtumista. Toisin sanoen, juuri tietoisuuden rakentuminen alussa, minuuden syntymisessä, on oppimisprosessin lähtökohta. Tämä prosessi ei ehkä aluksi ole kovin kehittynyt. Se on enemmänkin eleiden havainnointia ja niihin liittyvien toimintojen muistamista ja tunnistamista niiden toistuessa uudelleen. Vaikka tämä voidaankin ymmärtää samalla tavoin kuin Pavlov ymmärsi koiransa tai Skinner kyyhkystensä oppimisen, jotakin vielä perustavampaa tapahtuu lapsessa - tietoisuuden ja minuuden kasvaminen ja kehittyminen. On ehkä merkityksellistä, kun Luckmann (1967, 48-49) kirjoitti:

Henkilökohtaiset mieleenpalauttamis- ja ennakointiprosessit muodostavat muistimallin, johon sisältyy toisten yksilöiden muistoja ja odotuksia. Muodostuessaan osaksi sellaista mallia, subjektiiviset prosessit vakiintuvat; ne muodostuvat osaksi "objektiivista" todellisuutta... integroituvat sosiaalisissa suhteissa tietyksi, enemmän tai vähemmän yhtenäiseksi biografiaksi, josta yksilö on vastuullinen.

Nämä pohdinnat voidaan tiivistää seuraavasti. Irrottautuminen välittömästä kokemuksesta on lähtöisin kanssaihmisen kohtaamisesta face-toface -tilanteissa. Se johtaa tietoisuuden yksilöitymiseen ja tekee mahdolliseksi tulkinnallisten skeemojen, ja viimekädessä, merkitysjärjestelmien, syntymisen. Irrottautuminen välittömästä kokemuksesta täydentyy menneisyyden, nykyhetken ja tulevaisuuden yhdentyessä sosiaalisesti määräytyneeksi, moraalisesti relevantiksi henkilöhistoriaksi.

Näin Luckmannin mukaan nämä varhaiset oppimiskokemukset johtavat tietoisuuden ja minän muotoutumiseen. Tällöin ihmiskunta ylittää biologisen luontonsa ja tajuaa sen, mikä on erityisesti inhimillistä sen olemisessa. Juuri tästä oppimisen kautta syntyneestä tietojen, taitojen, asenteiden, arvojen, uskomusten, jne. varastosta rakentuu merkitysten moraaliuniversumi ja perusta tulevien kokemusten ymmärtämiselle.

Tämän jälkeen ihmiskunta toimii jokseenkin kuin eläin vaistojensa ohjaamana, pyrkien aina tasapainoon sosiaalisen ja fyysisen ympäristönsä kanssa. Tavallisen jokapäiväisen käyttäytymisen perusta on itsestään selvänä pidetyissä, epäproblemaattisissa tilanteissa. Tälle olettamukselle perustuu käsitys, ettei henkilöhistorian ja uusien kokemusten välillä ole ristiriitaa, tai kuten Schutz ja Luckmann $(1974,7)$ kirjoittavat:

Luotan, että maailma jatkuu sellaisena kuin sen tähän asti olen tuntenut, ja että se tietovarasto, jonka olen saanut kanssaihmisiltäni ja jota omat kokemukseni ovat muokanneet, tulee jatkossakin säilyttämään perimmäisen pätevyytensä... Tästä olettamuksesta seuraa uusi perusolettamus: että voin toistaa aikaisemmat onnistuneet tekoni. Niin kauan kuin maailman rakennetta voidaan pitää pysyvänä, niin kauan aikaisemmat kokemukseni ovat päteviä, kykyni toimia maailmassa jo vakiintuneella tavalla säilyy periaatteessa tallella.

Kuten eläin vaistoineen, voi tämä ihmisen tietoisuudeksi muodostunut kokemusperusta luoda tasapainon, jōka sallii ihmisten toimia ilman erityistä ajattelua. Aika näyttää kuluvan entiseen tahtiin, toimitaan sen enempää ajattelematta ja maailma menee menojaan. Kiinnostavaa onkin tämä asioiden pragmaattinen luonne, jota arkikokemus testaa, ja suurimmalta osalta se näyttää toimivan; voidaan elää kuten ennenkin. Mutta tässä kokemusperustassa ei olekaan kaikki, se ei riitä kun elämänkulkuun ilmaantuu poikkeuksia. Äkkiä jokin asia on ongelmallinen, sillä lukuisista syistä johtuen tietämyksemme on riittämätön vastaamaan ympäristömme haasteisiin. Syntyy ristiriita henkilökohtaisten kokemusten ja uuden tilanteen välille, jota ei voikaan ottaa itsestään selvyytenä.

Tähän kokemukseen Fromm viittasi kutsumalla sitä "väistämättömäksi epätasapainon tilaksi", sillä ihmisellä ei ole lajityypillistä elämisen tapaa. Moderni ihminen on yrittänyt luoda näitä malleja byrokratian sääntöjen ja määräysten avulla, jotta ihmisten väliset ongelmat voidaan ennakoida ja välttää niitä soveltamalla, mutta juuri näiden mallien rakentaminen onkin ihmisluonnon vastaista. Ihminen ei voi paeta tätä ongelmaa; ristiriita henkilökohtaisten kokemusten ja uusien tilanteiden välillä on kaiken oppimisen alku ja perusta, jolta ihmisen persoonaksi muotoutuminen lähtee. Kuten Bohm (1987, 33) väittää: "Niin kauan kuin asiat sujuvat, ei ole syytä kysellä", mutta kun ei ole mitään, jota voisi pitää itsestään selvänä, 
tuleekin välttämättömäksi tutkia ja kysyä. Tutkimusprosessi vaihtelee kuitenkin yksittäisen ihmisen kokemusten ja ehkäpä myös sen tilanteen mukaan, jossa ihmiset ovat kysymyksiä tehdessään. Joka tapauksessa kysyminen on toimintaa, jonka tavoitteena on löytää uudelleen tasapaino, ja se tapahtuu oppimisprosessin avulla.

\section{Oppiminen}

Oppiminen onkin tässä artikkelissa asetettu huomattavasti perustavampaan asemaan kuin joissakin niistä teorioista, jotka kasvatustieteilijät ovat omaksuneet, mutta johon aikuiskasvattajien eräät kysymykset viittaavat. Tässä jaksossa tutkitaan lyhyesti muutamia näistä kysymyksistä aikaisemman keskustelun valossa. Erityisesti kaksi kysymystä on tämän jakson keskiössä: henkilökohtaisten kokemusten ja uuden tilanteen välisen ristiriidan merkitys sekä kysymys minästä.

Edellä osoitettiin, että on tilanteita jolloin ei kokemusvarasto merkitysuniversumeineen ole riittävä uudesta tilanteesta selviytymiseksi jotain "tuntematonta" on tapahtunut; syntyy ristiriita aikaisemman ja uuden välille, jota Mezirow $(1981,7)$ kutsuu "orientoitumisen ongelmaksi" (disorientating dilemma).

Se on ongelma, johon ei näytä olevan yksilön aikaisemman kokemuksen pohjalta olemassa suoraa vastausta. Tämä tuntemattoman kokemusprosessi alkaa hyvin aikaisin yksilön elämässä, ja jatkuu sen läpi. Tämä on itse asiassa ihmislajin perusdikotomia - että ei ole lajinmukaisia ratkaisumalleja, on vain tuntemattomia tekijöitä. Tämä on perusluonteista ihmiselle. Jo Piaget (1929) tunnisti tämän eräässä lapsuutta käsittelevässä varhaisessa tutkimuksessaan. Lapset kyselevät useiden asioiden merkitystä kun heidän omat kokemuksensa eivät riitä vastaamaan ongelmaan, ja kun kokemusmaailma laajenee, kysymyksetkin muuttuvat. Moniin heidän ongelmiinsa voidaankin vastata empiirisen tiedon pohjalta, vaikkakaan aina tämä ei ole mahdollista. Aikuisena monet näistä kysymyksistä eivät ole nähtävissä yhtä selkeinä, mutta ne ovat silti olemassa. Aikaisempien kokemusten ja uusien ongelmien synnyttämä ristiriita on kuitenkin olemassa. Traumaattiset tapahtumat tekevät kysymyksistä avoimia - miksi tämä tapahtui minulle? Tämä on samantyyppinen tilanne, jonka Aslanian ja Brickell (1980) mainitsevat, kun he havaitsivat, että ihmiset, joilla oli jokin kriisi elämässään, olivat muita taipuvaisempia osallistumaan aikuiskasvatukseen. Kriisi ja siihen liittyvä muutos synnyttivät uuden tilanteen, johon ei ollutkaan ennalta olemassa ratkaisua, siitä aiheutui kysymys- ja ajatteluprosessi, joka aika ajoin toistuvana jatkuu läpi koko elämän.

Ihminen on, todellakin, kuten Fromm (1949) sanoo, ikuinen vaeltaja, joka ylitettyään biologisen luontonsa, ylittää myös muun luonnon. Tämän vuoksi ihmiset ovat tietoisia paitsi itsestään myös omista rajoituksistaan ja siksi heidän on selitettävä itselleen oma olemisensa. Ihminen etsii jatkuvasti merkitystä olemassaololleen, mikä merkitsee oppimista, ja aina kun syntyy ristiriita, havaitaan, ettei ole mitään absoluuttista vastausta vaan kaikki mitä ihminen keksii, on suhteellista. Frommin mukaan ihminen tajuaa toisinaan, että elämällä ei ole mitään muuta tarkoitusta, kuin se minkä ihminen itse sille antaa, ja että tämä tarkoitus on pätevä vain sikäli, kun se selviää uusien ongelmien asettamasta testistä. Aina kun kysymys tarkoituksesta nousee esiin, täytyy etsiä uudet vastaukset ja opetella ne. Olemassaolo on eräänlaista liikettä ristiriidasta harmoniaan ja takaisin. Itse asiassa ei voi oilla inhimillistä kehitystä ilman oppimiseen johtavia ristiriitoja. Tästä alkaa ja tässä on oppimisen ydin — on aina uudelleen vastattava elämän ongelmista nouseviin kysymyksiin, koska ei ole olemassa mitään lajityypillisiä ratkaisumalleja, ja ongelmiin vastaaminen on jatkuvaa ja kestää niin kauan kuin elämäkin.

Ristiriidan kokemus voi syntyä luonnollisesti silloin, kun tilanne on yksilölle uusi, tai se voi syntyä, kun jokin ulkopuolinen henkilö, kuten opettaja, aiheuttaa sen tai se voi olla jopa itse aiheutettu. Se voi syntyä silloin, kun yksilö saa uutta tietoa tai hänelle esitetään ongelma, johon hänellä ei ole aikaisemman tiedon pohjalta ratkaisua. Se voi syntyä jossain yksittäisessä tilanteessa tai formaalissa tai vapaassa ryhmässä. Se voi syntyä miellyttävässä tai epämiellyttävässä tilanteessa. Sen syntymiselle on loputon joukko tapoja ja mahdollisuuksia. Mutta se on kokemus, jota ei voi sivuuttaa; se aloittaa kysymyksen, ja siitä alkaa oppiminen.

Mitä sitten on oppiminen? On sanottu, että oppiminen on prosessi "muuntaa kokemus tiedoksi, taidoksi ja asenteiksi" (Jarvis 1987, 8). Oppiminen on myös prosessi, jossa annetaan merkitys merkityksettömille tilanteille; se on merkitysuniversumin rakentamista lisääntyneille tiedoille, taidoille ja asenteille tavoitteena kyetä selviytymään samanlaisissa tilanteissa tulevaisuudessa, vakiintuneella, vaistomaisella, ikäänkuin lajityypillisen mallin mukaisella tavalla.

Mutta merkittävä ero on siinä, että se ei voi olla lajityypillisen mallin mukaista, koska yksilön kokemus- ja merkitysrakenteista on muodostunut minä, joka on ylittänyt biologisen 
luonnon. Minä ei ole kokemisen objekti vaan sen subjekti, ja sen täytyy kasvaa ja kehittyä prosessissa, joka etenee ristiriitojen, oppimisen, harmonian ja jälleen ristiriitojen kautta. Kidd (1973, 130-131) korostaa että:

Kaikki oppijan uudet kokemukset symbolisoituvat ja organisoituvat jossain suhteessa minään, tai ne jäävät huomiotta koska havaittua suhdetta tai organisoitumista ei synny, tai niille annetaan virheellinen merkitys, koska kokemus näyttää yhteensopimattomalta minän rakenteen kanssa.

Kidd jatkaa, että tärkein tehtävä oppimisessa on kehittää minä, joka kykenee vuorovaikutukseen todellisuuden kanssa. Minä kehittyy oppimiskokemusten kautta aivan kuten sen muotoutumisvaiheessakin, mutta se ei ole eikä voi olla lopullisesti valmis, koska aina tulee olemaan ristiriitoja aikaisemmin opitun ja uuden välillä, ja aina tulee olemaan kysymyksiä kysyttävänä ja tietoa tavoiteltavana, eli kuten Fromm (1949, 49) asian ilmaisee: "Ihmisen elämä ... on jatkuvassa tasapainottomuuden tilassa." Ei ole olemassa mitään valmista lajityypillistä toimintamallia tai vaistoja. Ihminen on siten aina vasta tulossa - eikä koskaan valmis - vaikka onkin inhimillinen olento.

Juuri tässä suhteessa kysymys minästä, jonka monet aikuiskasvattajat ovat niin kaunopuheisesti ilmaisseet kirjoituksissaan, nousee etualalle. Minä on olemassa ja kehittyy vain elinikäisen oppimisen tuloksena.

\section{Johtopäätös}

Tämän artikkelin teesinä on, että koska ihmisellä ei ole vaistoihin pohjautuvia käyttäytymismalleja, aikaisempien kokemusten ja uusien ongelmatilanteiden välillä on aina olemassa ristiriidan mahdollisuus, ja että oppiminen on vastaus tähän ristiriitaan. Ja enemmänkin, juuri tämä on se oppimisprosessi, jonka kautta tietoisuus ja minä muovautuvat. Tässä on väistämätön paradoksi - ilman ristiriitaa ei voi olla oppimista ja ilman oppimista ei voi olla tietoisuutta ja minää, ja kuitenkin ihminen pyrkii aina tulemaan niin tutuksi ympäristönsä kanssa, että voisi käyttäytyä ennalta annetulla tavalla. Tämä on ihmisen paradoksi - että tietoisuus ja minä ovat oppimisen tulosta, sillä ihminen on sekä olemassa että tulemassa tai kuten Edgar Fauren (1972) raportti sen ilmaisee - ihmiskunta voi olla olemassa vain oppimisen kautta, mutta se on aina myös oppimassa olemaan, Learning to $\mathrm{Be}$.

\section{Kirjallisuus}

Aslanian, C\&Brickell, H. 1980. Americans in Transition. New York. College Board.

Bohm, D. 1987 Unfolding Meaning. ARK Paperbacks.

Faure, E. 1972. Learning to Be. Paris: Unesco.

Fromm, E. 1949. Man for Himself. London: Routledge and Kegan Paul.

Jarvis, P. 1987. Adult Learning in the Social Context. London: Croom Helm.

Kidd, J.R. ed. 1973. How Adults Learn. Chicago: Association Press.

Luckmann, T. 1967. The Invisible Religion. London. MacMillan.

Mezirow, J. 1981. A Critical Theory of Adult Learning and Education. Adult Education 32, 1, 1-24.

Piaget, J. 1929. The Child's Conception of the World. London: Routledge and Kegan Paul.

Schutz, A. \& Luckmann, T. 1973. The Structures of the Life World. London: Heinemann.

Strauss, A. ed. 1964. George Herbert Mead on Social Psychology. Chicago: University of Chicago Press. 


\title{
AIKUISKASVATUS \\ The Finnish Joumal of Adult Education \\ Vol. 9, 3/89 \\ ISSN 0358-6197 \\ Summary
}

\begin{abstract}
Jarvis, Peter 1989. Being and Leaming. Aikuiskasvatus 9,3 .

The article is an exploration into the philosophy of leaming. It makes few claims for leaming itself but seeks to locate it in relationship to human existence. All people learn, much of the time, for it is a part of the nature of the human condition, which is of not being in harmony with the surrounding environment. It is this that creates the questioning situation which is at the start of the process of human leaming.
\end{abstract}

